\title{
ETHNO-CULTURAL DEVELOPMENT OF CHILDREN OF PRESCHOOL AGE IN THE PROCESS OF CONNECTION TO DECORATIVE- APPLIED ART
}

\author{
Chernobrovkin Vladimir Alexandrovich ${ }^{1}$ \\ Bianca Carvalho Ferola ${ }^{2}$
}

\begin{abstract}
The article updates and substantiates the role of ethno-cultural education of Russian children of senior preschool age in the process of acquaintance with arts and crafts. The theoretical and methodological foundations of the ethno-cultural education of children of the senior preschool age are studied in the process of acquaintance with arts and crafts, the ethno-cultural education of preschool children as a social and psychological and pedagogical phenomenon is described, the state of program and methodical support for the realization of ethno-cultural education of preschool children in modern conditions of development of preschool education is analysed, the role of arts and crafts in ethnocultural education of children of senior preschool age in Russia is defined. The article suggests a set of measures, including a special program "We are wizards", aimed at the ethno-cultural education of senior preschoolers, which can be recommended to the mass practice of teachers of pre-school general educational institutions and teachers of additional education for children.
\end{abstract}

KEYWORDS: Ethno-culture. Ethno-cultural education. Folk culture. Arts and crafts. Ethno-cultural skill.

Desenvolvimento etno-cultural de crianças da idade pré-escolar no processo de ligação à arte decorativa aplicada

\footnotetext{
${ }^{1} \mathrm{PhD}$ in Philosophy. Nosov's Magnitogorsk State Tehnology University, Magnitogorsk, Rússia. E-mail: chernobrov.vl@mail.ru.

${ }^{2}$ Graduated in Biological Sciences.Federal Univesity of Uberlândia, Uberlândia, Minas Gerais, Brasil. E-mail: bcferola@gmail.com.
} 


\begin{abstract}
RESUMO
O artigo atualiza e substancia o papel da educação etno-cultural de crianças russas de idade pré-escolar no processo de familiarização com artes e artesanatos. Os fundamentos teóricos e metodológicos da educação etno-cultural de crianças da idade pré-escolar são estudados no processo de familiarização com artes e artesanatos, a educação etnocultural de pré-escolares como um fenômeno social, psicológico e pedagógico é descrito, o estado do programa e apoio metódico para a realização de educação etno-cultural de crianças em idade pré-escolar em modernas condições de desenvolvimento da educação pré-escolar é analisado, o papel das artes e artesanatos na educação etno-cultural de crianças de idade pré-escolar na Rússia é definido. O artigo sugere um conjunto de medidas, incluindo um programa especial "Somos feiticeiros", voltado para a educação etno-cultural de pré-escolares, que pode ser recomendado para a prática em massa de professores de instituições de educação geral pré-escolar e professores de educação complementar para crianças.
\end{abstract}

PALAVRAS-CHAVE: Etno-cultural. Educação etno-cultural. Cultura popular. Artes e artesanatos. Habilidade etno-cultural.

In modern conditions, the importance of processes related to the child's social development is actively growing in Russia. Accordingly, the role of preschool education as a factor in the child's successful development also increases. Preschool education in Russia, being the first independent level in the general education system, becomes particularly responsible in the implementation of educational activities in this age period. As modern educators note, at the present stage it is necessary to strengthen the direction of modern state policy in the field of preschool education to create conditions for ensuring accessibility and quality of preschool education (STEPANOVA et al, 2017). 
The relevance of ethno-cultural education is conditioned by the sociopolitical and cultural situation that has developed in Europe and the world, connected with the intensification of negative phenomena in the spiritual and moral direction, the tendencies towards disunity, national intolerance, the aggravation of the problem of adaptation in an inocultural environment, which places serious responsibility on pre-school education, childhood is the most important and favorable for the formation of ethno-cultural awareness and education of a preschool child.

Ethno-cultural traditions are of great importance in preserving the cultural heritage, the transfer of which is most significant in the period of pre-school childhood. In order to make the introduction of preschoolers to ethno-cultural traditions more successful, it is necessary to organize it in such a way that it creates a maximum of conditions that enable it to realize its potential. The goal of modern ethno-cultural education is the harmonization of the development of the personality of preschool children in the unity of spiritual, moral, socio-cultural, psychological criteria and constituent elements of such development: preservation of the native language, the richness of the ethno-cultural and spiritual heritage, inclusion in civil and state integrity by mastering the Russian language, state, legal basis of the Russian Federation, respect for the individual's right to cultural identity. As noted by modern researchers, a preschool child should receive timely professional help in order to gain social experience, take a worthy place in society, successfully develop as an individual (BABUNOVA et al., 8, 2015).

The main components of the formation of ethno-cultural education of a preschool child include:

- creation of conditions for the integral development of the child's personality through familiarization with the traditional folk culture;

- fostering respect for the culture of interethnic communication, tolerance, the ability to interact with the surrounding world; 
- creation of pedagogical conditions for the formation of ethno-cultural competences in preschool children.

Due to the fact that throughout their history people have tried to show their attitude to life, love of nature, their knowledge of beauty precisely in artistic form, decorative and applied art has great significance in ethnocultural education and development. In Russia, world renown received: the unique art of the Vologda lace-makers, the wonderful painting of Khokhloma, the folk art of Dymkovskaya, Gorodetsky toys, amazing with its bright, colorful colors. In all this, the giftedness of the Russian people, of its inexhaustible creative powers and talents is manifested. The beauty of the surrounding nature, the peculiarities of the people's way of life, its multifaceted talent, diligence, optimism appear before the preschoolers lively and directly in the works of folk craftsmen and masters. Acquaintance of preschool children with folk decorative and applied art contributes to the solution of the problem of moral, patriotic and artistic upbringing.

At present, the ideas of ethno-cultural education have been widely introduced into the practice of Russian pre-school institutions. But, nevertheless, special programs on the ethno-cultural education of preschool children through decorative and applied art are clearly not enough. There is no systematic approach to the use of ethno-cultural education and development in the pre-school educational process. The state of program and methodological support for the implementation of the introduction of children to ethno-cultural traditions is characterized by fragmentation and the absence of a single integrated approach. Existing modern programs on pre-school education only occasionally contain material on the ethnocultural education of preschool children at the regional level. Unique and unique in its kind to date, is the well-known in the South Urals of Russia and beyond its program-methodical complex "Our Home - South Ural", developed by the author's team of teachers from Magnitogorsk and Chelyabinsk under the scientific supervision of Professor E.S. Babunova 


\section{(CHELYABINSK REGIONAL DEPARTMENT OF THE RUSSIAN CHILDREN'S FUND, 2014).}

The system of Russian education at all times has been the main repository and translator of folk culture, influencing the formation of the mentality of the individual, in the education of patriotism and the culture of interethnic communication. The development of ethno-cultural experience contributes to the realization that the culture of a particular people is one of the forms of the cultural diversity of the world as a whole.

The concept of "ethno-culture" was constituted at the turn of the 20th and 21st centuries and began to be used as a speech reduction of the concept of "ethnic-culture", without having an exact definition. Modern researchers note that "ethno-culture", being a complex and internally contradictory hierarchy of sacred standards, socializes people, consolidates their cumulative activities, representing a single whole. "Ethno-culture" develops the individual not only as an intelligent and skilful being, but also as a bearer of religious, ethnic and interethnic experience. Modern researchers define this concept as a set of traditional values, attitudes and behavioral features embodied in the material, spiritual, social life of an ethnos formed in the past, developing in historical sociodynamics and constantly enriching ethnic specifics in various forms of people's self-realization (AFANASYEVA, 2009).

The researchers E.F. Vertyakova, A.P. Eliseeva, V.B. Mandzhieva, N.A. Minulina, V.V. Fashion ethno-culture is treated as the culture of an ethnos, which finds its expression in a certain ethnic identity of material and spiritual values that are manifested in moral and ethical norms, style of life, social facilities, kitchen, clothing, housing, etiquette, religion, language, folklore and psychological warehouse (ZENKOVA, 2012).

Thus, ethno-culture can be interpreted as the culture of a certain ethnos, where the storage of ethnic material and spiritual values is directly occurring. Personality as a subject of ethno-cultural is not only its consumer, but also the bearer and creator of cultural values that determine in their 
development the qualitative characteristics of the reproduction of ethnic experience.

Based on modern scientific approaches to the definition of the concept of "ethno-culture", it can be said that it is invariable in its manifestations, since its basis is tradition, not subject to the various changes that occur in the modern community, and is a stable form with established values, folk wisdom.

The concept of "ethno-cultural education and development" is closely connected with the concept of "ethno-cultural". The analysis of scientific works has shown that over the last decades this concept has actively become part of the everyday life of scientists and educators, but a single definition of this phenomenon has not yet been created. Ethno-cultural education is a complex social and pedagogical phenomenon, the basis of ethno-cultural education is the fundamental foundations of popular pedagogy, the theory of ethnos, ethno-psychology, philosophy, culture, social and cultural activities and other frontier branches of scientific knowledge. Ethno-cultural education is determined by introducing the knowledge of native folk culture, social norms of behavior, spiritual and moral values into the educational process; acquaintance with the cultural achievements of other nations; using the experience of popular education in order to develop children's interest in popular culture, the development of friendly relations with people of different nationalities (ZAKHAROVA, 2010).

Based on the views of modern researchers, "ethno-cultural education" can be determined:

- as a historically formed and developing activity of the ethnos on the creation, development and preservation of its own culture (ethnic holidays, traditions, customs, rituals, creations of national artistic creativity), in which ethnic self-awareness, ethnic stereotypes and the people's ethos are embodied;

- as the activities of various socio-cultural institutions, state and nonstate structures, which is aimed at researching, storing and developing 
traditional folk culture, translating its works and values into a modern socio-cultural space.

The methodological basis for the ethno-cultural education of preschool children in the second half of the nineteenth and early twentieth centuries was the well-founded K.D. Ushinsky, the idea of a nationality. The principle of the nationality defined as the base of education the native language, the study of the native history, customs and traditions of the people. A big role in the ethno-cultural education of children was played by a toy. Educational potential of toys was revealed by the well-known work "Toy - the joy of children", published under the editorship of N.D. Bartram, in which were collected and summarized materials on the multinational composition of the inhabitants of the Russian state. It contains illustrations with images of dolls in national costumes, ethnographic texts. Games with dolls that embodied the features characteristic of the peoples of the Russian state, developed the interest of children in the peculiarities of their life, work, national costumes, fun, brought invaluable benefits in the educational development of children.

Among the types of art and artistic creativity, one of the most vividly reflecting the folk culture, is applied arts. It always had and has deep folk roots. This is its distinctive feature. Modern researchers define it as an art form aimed at creating art products that have a practical purpose in public and private life, and artistic processing of utilitarian objects (utensils, furniture, textiles, clothes, toys, tools) (POGODINA, 2012).

Folk art as an expression of the creativity of the people is consonant in nature to the creativity of the child (simplicity, completeness of form, generalization of the image), and therefore it is easily perceived by him, it is clear to him. In connection with this, folk decorative and applied art is one of the most favorable and accessible means of ethno-cultural education of preschool children. It carries a huge spiritual charge, aesthetic and moral ideals, promotes the development of artistic taste, teaches to see and understand the beautiful in the surrounding life and in art. The reality 
surrounding the child is distinguished by a variety of social reference points, the contradictoriness of certain representations and knowledge that are formed as a result of a continuous flow of information. In search of integrity, in an effort to streamline this knowledge, teachers turn to history, seek to comprehend the pedagogical process in complex connections not only with the present, but also with the past. Particular importance is attached to this, which gives rise to a sense of imperishable values.

Speaking about the involvement of preschool children in decorative and applied art, first of all they pay attention to products of traditional kinds of folk art. In fact, works of folk craftsmen: carving and painting on wood, lacquer miniature and chasing, woven, lace and embroidered products, folk toy, glass and ceramics are evidences of talent, inexhaustible skill of artists from the people's environment. Fine examples of arts and crafts allow to educate preschoolers respect and love for the culture of their people, their native land.

Ethnic and cultural inclusion of preschoolers is possible in the integration of several educational areas. One of the most favorable in this respect for conducting classes in the visual arts is the artistic and aesthetic educational field. As noted by modern researchers, one of the important psychological and pedagogical conditions contributing to the achievement of the main targets of the Federal State Educational Standard of the preschool education standard in Russia is the atmosphere of high artistic and aesthetic development in the implementation of forms of communication between the child and the educator (CHERNOBROVKIN, 2016).

Decorative and applied art with its rich possibilities can significantly expand the knowledge and ideas of children about the culture of different peoples. Today, many pre-school organizations are aware of mini-museums; corners with mock-ups of household items, household utensils; specialized rooms, decorated in the traditions of different cultures; ethno-pedagogical centers on the formation of positive socialization of preschool children are being opened; various projects on intercultural issues are being 
implemented; Integrative approaches to the interaction of various modern cultures are used. However, in the real educational process of preschool children, there are many such organizations where there are not enough specialists and materials, and attention is not always paid to raising children in this direction.

In order to improve and optimize the ethno-cultural education of the children of the senior preschool age, which is the most acceptable and prepared, in one of the pre-school organizations of the Chelyabinsk region of Russia: MDOU No. 70 in Magnitogorsk, a study was conducted to identify the level of knowledge, as well as the formation of emotionally-valued judgments of children about the national arts and crafts. Twenty children of senior preschool age took part in the study. Determination of the level of knowledge of children of the senior preschool age about folk decorative and applied art was carried out with the help of the technique "Vernissage" O.A. Solomennikova (SOLOMENNIKOVA, 2000).

Diagnostic data showed that the knowledge of the majority of senior preschoolers about folk arts and crafts is at an average and low level, which indicates the need for focused work on the ethno-cultural education of children. The results were the basis for the development and testing of a special program, which was called "We are wizards", and is aimed at the ethno-cultural education of children of senior preschool age through arts and crafts.

The developed program on the ethno-cultural education of senior preschool children through arts and crafts contains methods and techniques for organizing activities on the use of works of decorative and applied art in ethno-cultural education. When creating the program, the recommendations of ES teachers were used E.S. Babunova, O.L. Knyazeva, M.D. Makhaneva, M.Yu. Novitskaya and others.

"We are wizards" - a partial (local) program of ethno-cultural education, designed to design the part formed by participants in educational 
relations. The program allows to realize and integrate the development of such educational areas as:

- cognitive development (familiarization with the history of folk crafts);

- speech development (a variety of folklore material, nursery rhymes, proverbs, fairy tales, etc.);

- social and communicative development (assimilation of social norms and values, development of communication and interaction of the preschool child with adults and peers);

- artistic and aesthetic development (assimilation of the characteristic features inherent in this or that kind of arts and crafts: composition, elements of the pattern, coloring of the painting, etc.).

The purpose of the implemented Program is the ethno-cultural education and development of children of the senior preschool age by means of arts and crafts. During the implementation of the main goal of the program, the following tasks were accomplished:

1. to create psychological conditions for the ethno-cultural development of older preschool children through decorative and applied art;

2. to develop in children a sense of color, form, composition, aesthetic perception;

3. to stimulate the development of the creative abilities of children.

As target targets after the implementation of the developed Program, it was assumed that the preschooler should:

- be able to distinguish and call the works of arts and crafts, their characteristics;

- to learn the distinctive features characterizing this or that kind of decorative and applied art: composition, elements of the pattern, rhythm, basic combinations, coloring of the painting, alternation of color spots in the pattern;

- master the skills, determine the sequence of painting, select and transfer the color of the desired painting. 
As conditions for the implementation of the program, the age of children (6-7 years) was determined, the period of implementation: 1 year; Thematic planning of the proposed program, which includes 18 general themes of classes (2 lessons per month) on four main topics: Dymkovo, Gorodets, Gzhel paintings and Polhov-Maidan, as well as goals for each lesson.

The work on the implementation of the program was organized according to a prospective plan. Dosage sessions - twice a month, for 30 minutes on certain days, which corresponds to the age characteristics of children of senior preschool age.

The following principles were based on the development of the developed Program:

- the principle of pedagogy of cooperation, as well as developmental learning, centered on: problem, dialogic, individualized;

- integration of educational areas;

- a complex thematic principle of building a general educational process;

- the principle of solving educational problems through joint, partner activities of the adult and children, as well as the independent activity of children.

For more optimal implementation of the proposed program, methodological recommendations were also developed, which are presented in the following provisions:

1. Including in the process of ethno-cultural education classes on decorative drawing, it must be remembered that for the successful mastery of children skills and skills in the implementation of a certain painting should take into account the age and individual characteristics of older preschoolers.

2. When working with preschool children, works of decorative and applied art with a floral design (Dymkovo and Gorodets painting, Gzhel painting, etc.) are applied. The teacher's task is to reveal to the preschoolers 
the variety and characteristic features of folk painting, the originality of the pattern, the composition, the combination of colors.

3 . Work on the ethno-cultural education of preschool children with the means of arts and crafts is organized in three main directions:

- familiarization of preschool children with the product of arts and crafts. At the same time, the task of emotional education of preschool children is solved: the ability to see and express their feelings caused by objects of folk art using folklore material;

- teaching decorative drawing should be carried out on the basis of genuine objects of arts and crafts;

- it is necessary to learn how to distinguish the characteristic features of a certain type of folk art, to find similarities and differences in products, to develop the ability to create patterns based on decorative and applied art.

Among the basic forms of training, group and individual classes were offered using methods and techniques, such as: classes in decorative drawing; conversation; the examination of genuine works of arts and crafts; exhibitions of arts and crafts; exhibitions of children's works in kindergarten and participation in city exhibitions of artistic creativity of children; collective and teamwork.

As a necessary equipment, children were offered visual material (illustrations, pictures, photos, video films), equipment and tools used for decorative drawing, as well as available folk artifacts and handicrafts that were inspected during the visit to the museum and exhibition hall.

The results of the re-diagnosis showed that purposeful work on the ethno-cultural education of preschool children through familiarization with arts and crafts made it possible to improve the knowledge of older preschool children about works of folk decorative and applied art. The level of emotional-value judgments also increased. This confirmed the effectiveness of a specially developed program and improved the knowledge of senior preschoolers about arts and crafts and its significance in the ethno-cultural education of children. 
Thus, similar programs and activities for their implementation aimed at the ethno-cultural education of preschool children can be recommended to the mass practice of teachers of pre-school educational institutions, as well as teachers of additional education organizations for children in Russia and other modern countries. As a result, the inclusion in the process of education and upbringing of children of preschool age classes on familiarization with folk decorative and applied art will be able to have a significant positive impact on raising the level of ethno-cultural education and development of preschool children.

\section{Referências}

AFANASYEVA, A.B. Azevedo de. Ethno-cultural education in Russia: theory, history, conceptual basis. 2009. Monograph. University Educational District of St. Petersburg and the Leningrad Region, St. Petersburg, 2009.

BABUNOVA, E.S. Et al. 3. Teoretiko-applied bases of socially-communicative development of preschool children. Magnitogorsk: 2015.

CHELYABINSK REGIONAL DEPARTMENT OF THE RUSSIAN CHILDREN'S FUND. 4. Our home is the Southern Urals: a program-methodical complex for organizations implementing educational programs for preschool education. 2014.

CHERNOBROVKIN, V. A. Artistic and aesthetic development in the system of preschool education. International Scientific and Research Journal, Yekaterinburg, No. 9 (51), p. 103-105, 2016. Available in: http://research-journal.org/wpcontent/uploads/2016/09/9-4-51.pdf . Acess in: 05/16/2019.

POGODINA, S.V. Theory and methods of development of children's fine arts. Moscow: Publishing Center "Academy", 2012.

SOLOMENNIKOVA, O.A. Programs of preschool educational institutions: methodical recommendations for employees of pre-school educational institutions. Moscow: Arcti, 2000.

STEPANOVA, N.A. Et al. Parental evaluation of preschool education quality: is it a problem or an opportunity? Man in India, T.97. № 5., p. 171-185, 2017.

ZAKHAROVA, L.M. Ethno-cultural education of children of preschool age in domestic pedagogy. Available in: http:/elar.urfu.ru/bitstream/10995/18926/1/iurp2010-85\%282\%29-05.pdf. Acess in: 05/16/201. 
ZENKOVA, L.G. Ethno-cultural environment as a psychological and pedagogical condition for the ethno-cultural education of preschool children in the children's art school. Bulletin of Tomsk Pedagogical University. n. 4, p. 195197. 2012.

Recebido em janeiro de 2019.

Aprovado em abril de 2019. 